\title{
A Novel Regeneration System for Tamarillo (Cyphomandra betacea) via Organogenesis from Hypocotyl, Leaf, and Root Explants
}

\author{
Jane Kahia ${ }^{1}$ \\ ICRAF Côte d'Ivoire Country Program, Cocody Mermoz 08 BP 2823 \\ Abidjan 08, Côte d'Ivoire
}

Peter Kanze Sallah

Faculty of Agriculture, National University of Rwanda (NUR), P.O. Box117, Huye, Rwanda

Lucien Diby and Christophe Kouame

ICRAF Côte d'Ivoire Country Program, Cocody Mermoz 08 BP 2823 Abidjan 08, Côte d'Ivoire

\section{Margaret Kirika \\ Institute of Water and Wetland Research, Department of Plant Physiology, Radboud University Nijmegen, Heyendaalseweg 135, 6525 AJ Nijmegen, The Netherland \\ Simeon Niyitegeka \\ Faculty of Agriculture, National University of Rwanda (NUR), Huye, Rwanda}

\section{Theodore Asiimwe \\ Rwanda Agriculture Board (RAB), 5016. Kigali, Rwanda \\ Additional index words. plantlet, Tamarillo, Cyphomandra betacea, growth regulators}

\begin{abstract}
Cyphomandra betacea (Cav.) is commonly known as Tamarillo or tree tomato. This species is mainly used for its edible fruits which have a high nutritional value and contain relatively high amounts of proteins, vitamins $B 6, C, E$, and provitamin $A$. The cultivation of Tamarillo in Rwanda is facing major challenges caused mainly by viral diseases such as Tamarillo mosaic virus (TaMV). These diseases are difficult to control and are transferred through vegetative propagation, often resulting in heavy productivity losses and poor-quality fruits. Thus, this study was conducted to evaluate the possibility of using tissue culture as an alternative propagation method. Tamarillo seeds were sterilized using a commercial bleach and germinated in vitro to get clean starting explants. Explants (hypocotyls, leaves, and roots) were cultured on semisolid Murashige and Skoog (MS) media supplemented with 6-benzylaminopurine (BA), N6-2-isopentyl adenine (2iP), 6-furfurylaminopurine (kinetin) evaluated at 5, 10, 20, $40 \mu \mathrm{M}$, and thidiazuron (TDZ), evaluated at 0.1, 0.5. 1.0 1.5 $\mu \mathrm{M}$ in separate experiments. Data were collected on the number of microshoots and roots 2 months after culture and analyzed using the Statistical Software for Social Sciences (SPSS) Software version 8. The results showed that the growth regulators evaluated had a significant $(P \leq 0.05)$ effect on plantlet regeneration from leaf and hypocotyl explants. The media supplemented with BA $40 \mu M$ was the most effective in inducing multiple shoots from leaf explants producing $4.67 \pm$ 0.15 shoots per explant. Root explants showed the least morphogenic responses for all the parameters evaluated. The regenerated plantlets were transplanted to the greenhouse and a survival rate of $90 \%$ was recorded. During this study, a simple, reproducible, single-step protocol was developed. These results would be useful for mass propagation of Tamarillo.
\end{abstract}

Cyphomandra betacea is a woody plant belonging to the Solanaceae family. It is commonly known as Tamarillo or tree

Received for publication 8 May 2015. Accepted for publication 19 June 2015.

${ }^{1}$ Corresponding author. E-mail: j.kahia@cgiar.org. tomato (Correia et al., 2009). The name "Tamarillo" was adopted in New Zealand and has become the standard commercial designation for the fruit (Morton, 1987). Tamarillo is grown mainly for their edible fruits and, to a lesser extent, as an outdoor ornamental. They have several culinary uses and can be eaten raw in salads or as dessert but preferably cooked (Guimarães et al., 1996). In Jamaica and the West Indies, the fruits are considered to have beneficial effects in relieving disorders of the liver (Guimarães et al., 1996).

Tamarillo is an important component in Rwanda's exotic fruit industry and consumption of the fruit is traditionally recommended for people suffering from stomach ailments. In this country, it is mainly used for making jams and juices but unfortunately in low quantities because of low productivity, mainly due to viral diseases. Tamarillo is considered an interesting crop from the nutritional viewpoint as it is comparatively high in protein (1.5-2 g/100 $\mathrm{g}$ of food), vitamin C $(30-45 \mathrm{mg} / 100 \mathrm{~g})$, and $\mathrm{E}(1.85 \mathrm{mg} / 100 \mathrm{~g})$, provitamin $\mathrm{A}$, mineral elements $(\mathrm{K}, \mathrm{P})$, low in carbohydrates $(4.7 \mathrm{~g} / 100 \mathrm{~g})$, and in calories (about $28 \mathrm{Kcal} / 100 \mathrm{~g}$ ) (McCane and Widdowson, 1992). The plant is propagated mainly through seeds, cuttings, or by grafting (Fouque, 1973; Prohens et al., 2001). Propagation through seeds is not recommended as this method is known to produce high degree of genetic variability that negatively affects fruit color resulting in rejection of fruits on the international market. On the other hand, vegetative propagation by cuttings has been found to transmit deadly viral diseases. Therefore, there is a compelling need to develop alternative methods to propagate the plant in Rwanda. Tissue culture offers a feasible solution to produce large numbers of diseasefree planting materials. It is also known that in vitro propagated Tamarillo plants produce higher yields and shorter gestation period compared with traditional methods (The Indian Agriculture Information Wing, 2009). Another advantage offered by tissue culture methods is the large scale availability of planting materials at any time of the year irrespective of the season. This study aimed to developing an efficient and rapid propagation protocol for $C$. betacea plant through tissue culture techniques.

An increasing number of studies describing in vitro propagation of Tamarillo using axillary buds have been reported (Barghchi, 1998; Obando et al., 1992; Waweru et al., 2011). Somatic embryogenesis has also been reported by Espinosa et al. (2005), Obando and Jordan (2001), Correia et al. (2009), Guimarães et al. (1996), and Correia et al. (2011). However, there are no documented studies on the direct organogenesis in Tamarillo. An important advantage of direct organogenesis is the potential for maintaining genomic stability of regenerated plants, whereas regeneration via an intermediate callus phase increases the possibility of somaclonal variations (Kahia, 1999). Furthermore, a highly efficient and reproducible in vitro regeneration system is an absolute prerequisite for producing transgenic plants.

\section{Materials and Methods}

The study was conducted at the plant tissue culture laboratory of Rwanda Agriculture Board (RAB) located in Rubona, Southern 
Province of Rwanda (Altitude: $1630 \mathrm{~m}$ $2^{\circ} 29^{\prime} 07^{\prime \prime} \mathrm{S}, 29^{\circ} 47^{\prime} 49^{\prime \prime} \mathrm{E}$ ). Seeds of a highyielding Tamarillo variety called Imbundi were harvested from the main growing region in Musanze, Northern Rwanda. They were washed in tap water for 5 min to remove the mucilage, dried under shade for a week before being transferred to the cabinet for sterilization. Sterilization was carried out by immersion in $70 \%$ ethanol for $30 \mathrm{~s}$, followed by $3 \%$ commercial bleach called JIK which contains $3.85 \% \mathrm{NaOCl}$ [Reckitt and Benckiser (Kenya) Ltd] for $20 \mathrm{~min}$ and a final rinse with sterile distilled water four times.

The seeds were germinated on a Murashige and Skoog media (1962) and incubated in a growth room maintained at $25{ }^{\circ} \mathrm{C}$ and $16 \mathrm{~h}$ photoperiod for 2 months. Explants (hypocotyls, leaves, and roots) harvested from the in vitro germinated plants using a sterile surgical blade and cut into $1 \mathrm{~cm}^{2}$ leaf explants and $5 \mathrm{~mm}$ in length for the hypocotyl and root explants. Each of the explant was cultured singly in a test tube.

The composition of the culture media was half strength MS medium supplemented with TDZ at $0.1,0.5,1.0$, and $1.5 \mu \mathrm{M} ; 2 \mathrm{iP}$, kinetin and BA each at 5, 10, 20, and $40 \mu \mathrm{M} 20 \mathrm{~g} / \mathrm{L}$ sucrose, $100 \mathrm{mg} / \mathrm{L}$ Myo-inositol, $40 \mathrm{mg} / \mathrm{L}$ ascorbic acid, $40 \mathrm{mg} / \mathrm{L}$ arginine, $40 \mathrm{mg} / \mathrm{L}$ adenine, $100 \mathrm{mg} / \mathrm{L}$ casein hydrolysate and gelled with $7 \%$ agar. The media without growth regulators is hereby referred to as control. All the chemicals used in this study were from Sigma-Aldrich Schnelldorf Germany. The media $\mathrm{pH}$ was adjusted to 5.8 by using either $1 \mathrm{~N} \mathrm{HCL}$ or $1 \mathrm{~N} \mathrm{NaOH}$ before the gelling agent was added. The media were then heated on a hot plate with continuous stirring using a magnetic stirrer until agar was dissolved and $20 \mathrm{ml}$ media dispensed in the tubes. The tubes were covered with caps, placed in test tube holders and autoclaved using an Astell Hearson 2000 series autoclave set to operate at a temperature of $121{ }^{\circ} \mathrm{C}$ and pressure of $1.1 \mathrm{~kg} \cdot \mathrm{cm}^{-2}$ (103.5 kpa) for $20 \mathrm{~min}$.

The explants were cultured on the media under evaluation and incubated in growth rooms maintained at $25 \pm 2{ }^{\circ} \mathrm{C}$ and $16 \mathrm{~h}$ photoperiod. Subculturing was done every 4 weeks.

All trials were laid out in completely randomized design with 16 replicates and the experiments repeated three times. Assessment of the number of microshoots and roots per explant were carried out after 2 months for all the experiments.

Twenty of the regenerated plantlets were removed from the culture tubes and thoroughly washed under running tap water to get rid of any agar adhering to the roots. They were taken to the greenhouse where they dipped in 2\% copper-based fungicide (Redomil) for $10 \mathrm{~min}$. Meanwhile, plastic pots $\left(25 \times 25 \mathrm{~cm}^{2}\right)$, were filled with sterile potting mixture composed of top soil, sand, manure mixed in the ratio of $3: 2: 1$ (weight/weight) and immersed in a basin containing tap water. The pots were then removed from the basin with water once the potting mixture was saturated with water and the plantlets carefully transplanted. The plants were irrigated every week with tap water using a handoperated sprayer. No fertilizer was applied at this stage. The plantlets were covered with polythene tubing to create high relative humidity. After 2 weeks, two holes were punctured on the polythene tubing to reduce the relative humidity and the tubing was finally removed after 1 month.

Data were subjected to analysis of variance to test the treatment effects using the Statistical Software for Social Sciences (SPSS) package version 8. Means separation was done using Duncan test.

\section{Results and Discussion}

Effect of TDZ on in vitro plantlet regeneration from Tamarillo hypocotyls, leaves, and roots explants. Microshoot initials were first observed on the hypocotyl and leaf explants after only 2 weeks of culture. In the case of root explants, microshoot initials were not observed until 3-4 weeks of culture. Figure $1 \mathrm{~A}-\mathrm{C}$ shows microshoot regeneration from hypocotyl explant after 2, 3, and 4 weeks, respectively. There were no microshoots regenerated from the root explants when TDZ was evaluated at $0.1,0.5$, and $1.0 \mu \mathrm{M}$ (Table 1). On the other hand, microshoots regenerated from leaf explants did not develop roots when TDZ was evaluated at 0.1 and $0.5 \mu \mathrm{M}$. TDZ evaluated at $1.0 \mu \mathrm{M}$ produced the highest $(3.6 \pm 0.3)$ mean number of microshoots from hypocotyl explants. These results are similar to those of study by Lata et al. (2013) who reported that TDZ evaluated at $1.0 \mu \mathrm{M}$ gave the highest mean number of shoots in Stevia rebaudiana, Bertoni, a medicinal plant of the sunflower family. In this study, TDZ evaluated at a concentration of more than $1 \mu \mathrm{M}$ was found to decrease the number of plantlets generated from both leaf and hypocotyl explants. Similarly, Khan et al. (2006) and Aboshama (2011) reported that TDZ concentrations higher than $1 \mu \mathrm{M}$ reduced morphogenic responses in Capsicum annuum, pepper. In vitro application of TDZ induces a range of responses in explant tissues; from callusing (Dadjo et al., 2015; Manisha and Patel, 2013) to direct shoot organogenesis (Lata et al., 2013) and somatic embryogenesis (Khan et al., 2006). These responses vary widely depending on TDZ concentration, exposure time, type of explant, and species (Mehta et al., 2004). It is believed that TDZ is less susceptible to the plant's degrading enzymes and is active at lower concentrations than the adenine-type cytokinins (Mok et al., 1987). In this study, hypocotyl explants were found to be more responsive than leaf explants, and root explants were the least responsive. TDZ evaluated at $1 \mu \mathrm{M}$ was observed to be the best growth regulator for in vitro regeneration of Tamarillo plantlets. This was not surprising since it is known that plant growth regulators influence in vitro organogenesis in different species, in diverse ways. These variations are because different species, organs, or section of organs differ in their ability to produce endogenous growth substances. In addition, the different species and organs show various abilities to recognize, take up, transport, metabolize, and respond to exogenous plant growth regulators (Cheesman et al., 2010).

Effect of $2 i P$ on in vitro plantlet regeneration from Tamarillo hypocotyls, leaves and roots explants. The leaf explants cultured on media supplemented with $20 \mu \mathrm{M}$ $2 \mathrm{iP}$ produced the highest $(4.11 \pm 0.09)$ mean number of microshoots although it was not significantly different from the numbers obtained with 2 iP $40 \mu \mathrm{M}$ (Table 2). Increasing the concentration of $2 \mathrm{iP}$ from 5 to $40 \mu \mathrm{M}$ was found to significantly reduce the mean number of microshoots obtained from hypocotyl explants (Table 2). These results are in agreement with those of (Waweru et al., 2011) who found that increasing the concentration of $2 \mathrm{iP}$ from 5 to $40 \mu \mathrm{M}$ in the media significantly reduced the mean number of microshoots obtained from Tamarillo nodal explants. In this study, the optimum $2 \mathrm{iP}$ concentration was found to be dependent on the explant type. For the hypocotyl explants, the optimum $2 \mathrm{iP}$ concentration was $5 \mu \mathrm{M}$ whereas for leaf explants it was $20 \mu \mathrm{M}$. $2 \mathrm{iP}$ is not very often used in tissue culture; however, exogenous $2 \mathrm{iP}$ has been shown to have beneficial effect on adventitious shoot formation for some plants (Maity et al., 2005; Mathew et al., 1999).

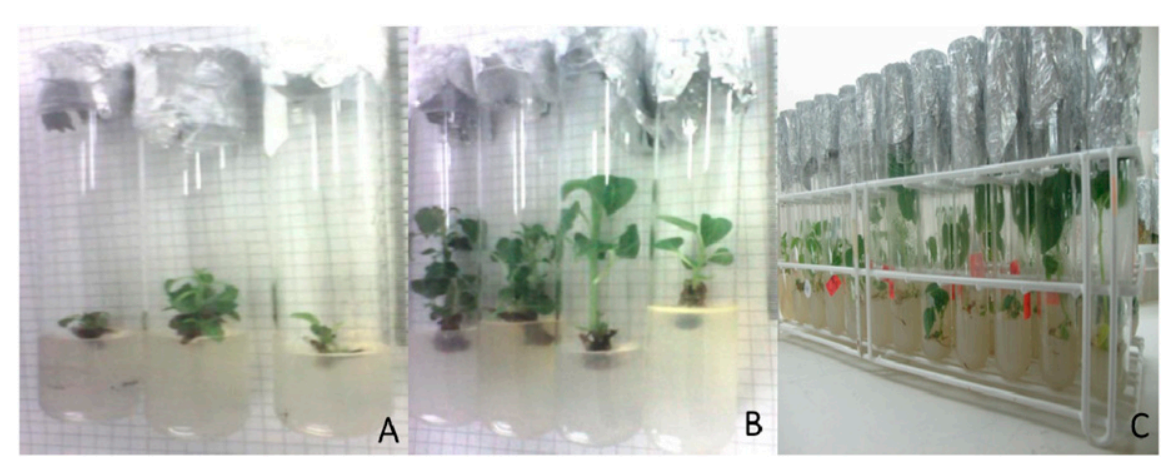

Fig. 1. Microshoot regeneration from hypocotyl explants using TDZ. (A) 2 weeks, (B) 3 weeks, and (C) 4 weeks after culture. 
Table 1. Effects of different TDZ concentrations on microshoot and root proliferation from cultured Tamarillo hypocotyl, leaf and root explants.

\begin{tabular}{|c|c|c|c|c|c|c|}
\hline \multirow[b]{2}{*}{$\begin{array}{l}\text { TDZ concentration } \\
\text { in } \mu \mathrm{M}\end{array}$} & \multicolumn{2}{|c|}{ Hypocotyl explants } & \multicolumn{2}{|c|}{ Root explants } & \multicolumn{2}{|c|}{ Leaf explants } \\
\hline & $\begin{array}{l}\text { Mean no. of } \\
\text { microshoot } \pm \text { SE }\end{array}$ & $\begin{array}{l}\text { Mean no. of } \\
\text { root } \pm \text { SE }\end{array}$ & $\begin{array}{l}\text { Mean no. of } \\
\text { microshoot } \pm \text { SE }\end{array}$ & $\begin{array}{l}\text { Mean no. of } \\
\text { root } \pm \text { SE }\end{array}$ & $\begin{array}{l}\text { Mean no. of } \\
\text { microshoot } \pm \text { SE }\end{array}$ & $\begin{array}{l}\text { Mean no. of } \\
\text { root } \pm \mathrm{SE}\end{array}$ \\
\hline$\overline{0.1}$ & $2.34 \pm 0.11 \mathrm{a}$ & $1.00 \pm 0.03 \mathrm{a}$ & $0.00 \pm 0.00 \mathrm{a}$ & $3.50 \pm 0.10 \mathrm{c}$ & $0.78 \pm 0.07 \mathrm{a}$ & $0.00 \pm 0.00 \mathrm{a}^{*}$ \\
\hline 1 & $3.56 \pm 0.26 \mathrm{~b}$ & $2.44 \pm 0.08 b$ & $0.00 \pm 0.00 \mathrm{a}$ & $1.80 \pm 0.15 \mathrm{a}$ & $2.78 \pm 0.05 b$ & $1.56 \pm 0.05 \mathrm{~b}$ \\
\hline 1.5 & $2.78 \pm 0.10 \mathrm{a}$ & $1.22 \pm 0.05 \mathrm{a}$ & $0.33 \pm 0.02 \mathrm{~b}$ & $4.30 \pm 0.15 b$ & $0.67 \pm 0.06 \mathrm{a}$ & $1.11 \pm 0.00 \mathrm{~b}$ \\
\hline
\end{tabular}

*Means followed by the same letter are not significantly different at $P>0.01$.

$\mathrm{TDZ}=$ thidiazuron

Table 2. Effects of different $2 \mathrm{iP}$ concentrations on microshoot and root proliferation from cultured Tamarillo hypocotyl, leaf and root explants.

\begin{tabular}{|c|c|c|c|c|c|c|}
\hline \multirow[b]{2}{*}{$\begin{array}{l}2 \mathrm{iP} \text { conc } \\
\text { in } \mu \mathrm{M}\end{array}$} & \multicolumn{2}{|c|}{ Hypocotyl explants } & \multicolumn{2}{|c|}{ Root explants } & \multicolumn{2}{|c|}{ Leaf explants } \\
\hline & $\begin{array}{l}\text { Mean no. of } \\
\text { microshoot } \pm \text { SE }\end{array}$ & $\begin{array}{l}\text { Mean no. of } \\
\text { root } \pm \text { SE }\end{array}$ & $\begin{array}{c}\text { Mean no. of } \\
\text { microshoot } \pm \text { SE }\end{array}$ & $\begin{array}{l}\text { Mean no. } \\
\text { of root } \pm \text { SE }\end{array}$ & $\begin{array}{c}\text { Mean no. of } \\
\text { microshoot } \pm \text { SE }\end{array}$ & $\begin{array}{c}\text { Mean no. of } \\
\text { root } \pm \text { SE }\end{array}$ \\
\hline 5 & $4.10 \pm 0.14 \mathrm{c}$ & $2.44 \pm 0.10 \mathrm{c}$ & $0.00 \pm 0.00 \mathrm{a}$ & $1.67 \pm 0.08 \mathrm{~b}$ & $1.10 \pm 0.10 \mathrm{a}$ & $1.00 \pm 0.09 \mathrm{~b}^{*}$ \\
\hline 10 & $1.56 \pm 0.02 \mathrm{a}$ & $1.44 \pm 0.08 \mathrm{~b}$ & $1.00 \pm 0.05 \mathrm{~b}$ & $0.83 \pm 0.06 \mathrm{~b}$ & $1.33 \pm 0.12 \mathrm{a}$ & $1.89 \pm 0.08 \mathrm{~b}$ \\
\hline 20 & $3.11 \pm 0.17 \mathrm{~b}$ & $2.56 \pm 0.12 \mathrm{c}$ & $0.00 \pm 0.00 \mathrm{a}$ & $0.00 \pm 0.00 \mathrm{a}$ & $4.11 \pm 0.09 \mathrm{~b}$ & $3.78 \pm 0.14 \mathrm{c}$ \\
\hline 40 & $2.23 \pm 0.19 \mathrm{a}$ & $0.00 \pm 0.00 \mathrm{a}$ & $0.00 \pm 0.00 \mathrm{a}$ & $0.00 \pm 0.00 \mathrm{a}$ & $4.00 \pm 0.13 \mathrm{~b}$ & $0.00 \pm 0.00 \mathrm{a}$ \\
\hline
\end{tabular}

* Means followed by the same letter are not significantly different at $P>0.01$.

$2 \mathrm{iP}=\mathrm{N} 6-2$-isopentyl adenine.

Table 3. Effects of different BA concentrations on microshoot and root proliferation from cultured Tamarillo hypocotyl, leaf and root explants.

\begin{tabular}{|c|c|c|c|c|c|c|}
\hline \multirow[b]{2}{*}{$\begin{array}{l}\text { BA conc in } \\
\mu \mathrm{M}\end{array}$} & \multicolumn{2}{|c|}{ Hypocotyl explants } & \multicolumn{2}{|c|}{ Root explants } & \multicolumn{2}{|c|}{ Leaf explants } \\
\hline & $\begin{array}{l}\text { Mean no. of } \\
\text { microshoot } \pm \text { SE }\end{array}$ & $\begin{array}{c}\text { Mean no. of } \\
\text { root } \pm \mathrm{SE}\end{array}$ & $\begin{array}{l}\text { Mean no. of } \\
\text { microshoot } \pm \text { SE }\end{array}$ & $\begin{array}{l}\text { Mean no. of } \\
\text { root } \pm \text { SE }\end{array}$ & $\begin{array}{l}\text { Mean no. of } \\
\text { microshoot } \pm \text { SE }\end{array}$ & $\begin{array}{l}\text { Mean no. of } \\
\text { root } \pm \text { SE }\end{array}$ \\
\hline 5 & $2.23 \pm 0.13 \mathrm{~b}$ & $0.00 \pm 0.00 \mathrm{a}$ & $0.00 \pm 0.00 \mathrm{a}$ & $0.00 \pm 0.00 \mathrm{a}$ & $0.57 \pm 0.03 \mathrm{a}$ & $0.00 \pm 0.00 \mathrm{a}^{*}$ \\
\hline$\underline{40}$ & $3.24 \pm 0.21 \mathrm{c}$ & $2.90 \pm 0.13 \mathrm{~b}$ & $0.00 \pm 0.00 \mathrm{a}$ & $0.67 \pm 0.05 \mathrm{~b}$ & $4.67 \pm 0.15 \mathrm{c}$ & $2.23 \pm 0.17 \mathrm{~b}$ \\
\hline
\end{tabular}

*Means followed by the same letter are not significantly different at $P>0.01$.

$\mathrm{BA}=6$-benzylaminopurine.

Table 4. Effects of different 6-furfurylaminopurine (kinetin) concentrations on microshoot and root proliferation from cultured Tamarillo hypocotyl, leaf and root explants.

\begin{tabular}{|c|c|c|c|c|c|c|}
\hline \multirow[b]{2}{*}{$\begin{array}{l}\text { Kinetin concentration } \\
\text { in } \mu \mathrm{M}\end{array}$} & \multicolumn{2}{|c|}{ Hypocotyl explants } & \multicolumn{2}{|c|}{ Root explants } & \multicolumn{2}{|c|}{ Leaf explants } \\
\hline & $\begin{array}{l}\text { Mean no. of } \\
\text { microshoot } \pm \text { SE }\end{array}$ & $\begin{array}{c}\text { Mean no. of } \\
\text { root } \pm \text { SE }\end{array}$ & $\begin{array}{l}\text { Mean no. of } \\
\text { microshoot } \pm \text { SE }\end{array}$ & $\begin{array}{c}\text { Mean no. of } \\
\text { root } \pm \mathrm{SE}\end{array}$ & $\begin{array}{l}\text { Mean no. of } \\
\text { microshoot } \pm \text { SE }\end{array}$ & $\begin{array}{c}\text { Mean no. } \\
\text { of root } \pm \mathrm{SE}\end{array}$ \\
\hline$\overline{5}$ & $0.67 \pm 0.07 \mathrm{a}$ & $3.1 \pm 0.10 \mathrm{c}$ & $0.0 \pm 0.0 \mathrm{a}$ & $1.0 \pm 0.05 \mathrm{a}$ & $1.67 \pm 0.06 \mathrm{~b}$ & $0.0 \pm 0.0 \mathrm{a}^{*}$ \\
\hline 20 & $0.22 \pm 0.02 \mathrm{a}$ & $2.1 \pm 0.11 \mathrm{~b}$ & $0.0 \pm 0.0 \mathrm{a}$ & $0.97 \pm 0.03 \mathrm{a}$ & $0.0 \pm 0.0 \mathrm{a}$ & $1.3 \pm 0.07 \mathrm{~b}$ \\
\hline 40 & $0.89 \pm 0.08 \mathrm{a}$ & $0.8 \pm 0.07 \mathrm{a}$ & $1.67 \pm 0.13 \mathrm{~b}$ & $1.2 \pm 0.05 \mathrm{a}$ & $1.11 \pm 0.1 \mathrm{~b}$ & $1.5 \pm 0.02 \mathrm{~b}$ \\
\hline
\end{tabular}

*Means followed by the same letter are not significantly different at $P>0.01$.

Effect of BA on in vitro plantlet regeneration from Tamarillo hypocotyls, leaves and roots explants. The leaf explants cultured on media supplemented with BA $40 \mu \mathrm{M}$ produced the highest $(4.67 \pm 0.15)$ mean number of microshoots and the highest mean number of roots (Table 3 ). The results of this study agree with those of Guimarães et al. (1996), who reported BA was the most effective in shoot differentiation in Tamarillo. In this study, increasing the concentration of BA increased the mean number of microshoots from both hypocotyl and leaf explants. This is in agreement with earlier work by Ndoye et al. (2003) and Vasudevan et al. (2001) who reported that in vitro shoot multiplication occurs in on media supplemented with high BA concentration. Similarly, the importance of the application of high BA concentration to initiate

HortScience Vol. 50(9) September 2015

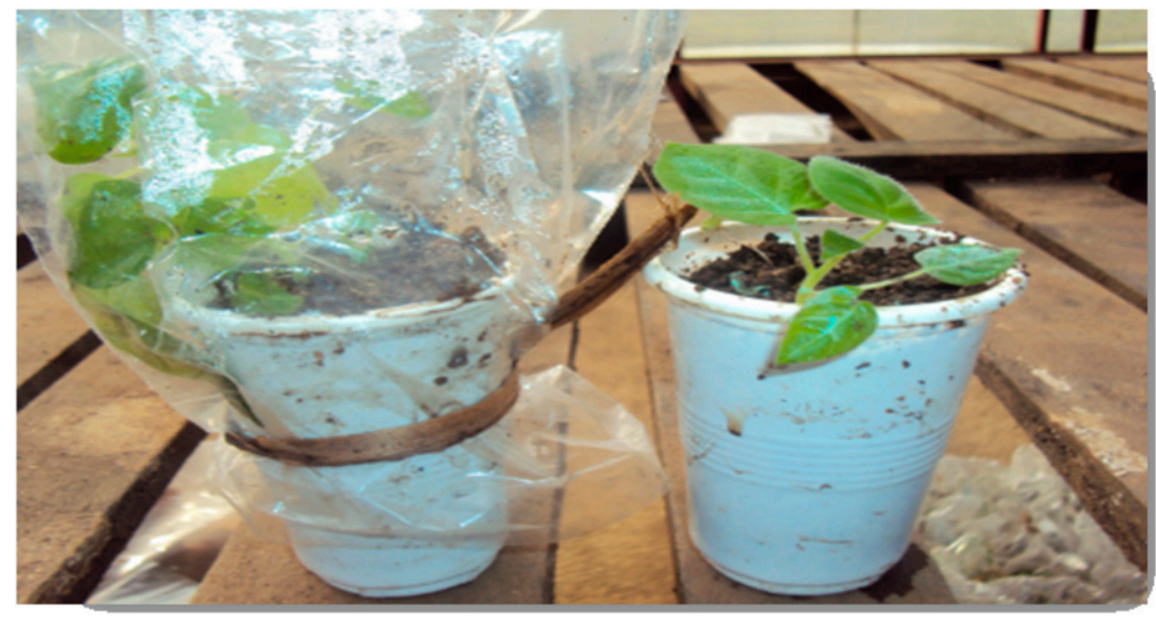

Fig. 2. In vitro regenerated Tamarillo Plantlets growing in the greenhouse. 
bud formation from explants were reported by Zaffari et al. (2000) and Subramaniam et al. (2008) in Cavendish banana cultivar Brasilian (AAA). However, the results are contrary to many reports that indicate that there is reduction in number of shoots in media supplemented with cytokinins concentrations higher than optimal level (Burbulis et al., 2011; Rai et al., 2009). The root explants cultured on media supplemented with BA in all the different concentrations did not produce any microshoots. Interestingly, leaf explants were found to have better regeneration capability than the hypocotyl explants when cultured on BA supplemented media.

Effect of kinetin on in vitro plantlet regeneration from Tamarillo hypocotyls, leaves, and roots explants. Leaf explants cultured on media supplemented with 10 $\mu \mathrm{M}$ kinetin produced the highest $(3.5 \pm$ 0.13 ) mean number of microshoots per leaf explant. However, this concentration was observed to inhibit root formation (Table 4). Increasing the concentration of kinetin from 5 to $40 \mu \mathrm{M}$ significantly reduced the mean number of roots from the microshoots obtained from hypocotyl explants. Root explants cultured on media supplemented with kinetin did not produce any microshoots except on media containing $40 \mu \mathrm{M}$ kinetin. The differential ability of cytokinins to induce shoot formation could be attributed to factors such as stability, rate of conjugation, and oxidation of the hormones (D'Onofrio and Morini, 2005). Thus, the presence of hormones appears to be a determining factor for the successful enhancement of adventitious bud formation and shoot proliferation.

Acclimatization. Twenty in vitro propagated plants were taken from the laboratory to the greenhouse for acclimatization and $90 \%$ survival rate was recorded after 2 months. Visual observation of the plantlets did not show any morphological abnormalities and they grew vigorously (Fig. 2).

\section{Conclusion}

This study reveals that organogenesis in Cyphomandra betacea is dependent on the type and concentration of growth regulators, as well as explants used. During this study, a simple reproducible single-step protocol using leaf explants cultured on media supplemented with BA $40 \mu \mathrm{M}$ was developed for in vitro propagation of Tamarillo.

\section{Literature Cited}

Aboshama, H.M.S. 2011. Direct somatic embryogenesis of pepper (Capsicum annuиm L.). World J. Agr. Sci. 7:755-762.
Barghchi, M. 1998. In vitro regeneration, plant improvement and virus elimination of Tamarillo [Cyphomandra betacea (Cav.) Sendt)], p. 173-185. In: M.R. Davey, et al. (eds.) Tree biotechnology-towards the millennium. Nothingham University Press, Nothingham, UK.

Burbulis, N., A. Blinstrubiene, and R. Kuprienè. 2011. Effect of genotype and medium composition on linseed (Linum usitatissimum) ovary culture. Biologia 66:465-469.

Cheesman, L., J.F. Finnie, and J. Van Staden. 2010. Eucomis zambesiaca baker:Factors affecting in vitro bulblet induction. SOUTH AFRIC. J. Bot. 76:543-549.

Correia, S.I., M.L. Lopes, and J.M. Canhoto. 2009. Somatic embryogenesis in Tamarillo (Cyphomandra betacea): Recent advances. Acta Hort. 839:157-164.

Correia, S.I., M.L. Lopes, and J.M. Canhoto. 2011. Somatic embryogenesis induction system for cloning an adult Cyphomandra betacea (Cav.) Sendt. (Tamarillo). Trees (Berl.), doi: 10.1007/ s00468-011-0575-5.

Dadjo, C., J. Kahia, D. Sila, C. Muthuri, L. Diby, and C. Kouame. 2015. Induction and regeneration of somatic embryos from Vitex doniana (Lamiaceae) leaf explants. Intl. J. Biotechnol. Mol. Biol. Res. 6:28-34.

D'Onofrio, C. and S. Morini. 2005. Development of adventitious shoots from in vitro grown Cydonia oblonga leaves as influenced by different cytokinins and treatment duration. Biol. Plant. 49:17-21.

Espinosa, O., A. John, T.O. Gonzalez, H. Sanchez, R. A, A. Kafrri, and C. Londono. 2005. Potential of in vitro propagation for the tomato TREE PARTENOCARPIC Cyphomandra betacea Cav. (sendt). Rev. Fac. Nal. Agr. Medellín 58(1):2685-2695.

Fouque, A. 1973. Solanacées. Fruits 28:41-42.

Guimarães, M.L., M.C. Tomé, and G.S. Cruz. 1996. Cyphomandra betacea (Cav.) sendt, (Tamarillo), p. 120-137. In: Y.P.S. Bajaj (ed.). Biotechnology in agriculture and forestry, trees IV. Springer Verlag, Berlin.

Kahia, W.J. 1999. In vitro propagation of the new Coffea arabica cultivar-Ruiru 11. University of London, London, $\mathrm{UK}, \mathrm{PhD}$ thesis.

Khan, H., I. Siddique, and M. Anis. 2006. Thidiazuron action inhibitor silver nitrate induced somatic embryogenesis and plant. Acta Physiol Plant 26(3):299-305.

Lata, H., S. Chandra, Y.H. Wang, V. Raman, and I.A. Khan. 2013. TDZ-induced high frequency plant regeneration through direct shoot organogenesis in Stevia rebaudiana Bertoni: An important medicinal plant and a natural sweetener. Amer. J. Plant Sci. 4:117-128.

Manisha, B.P. and R.S. Patel. 2013. Impact of plant growth regulators (PGRs) on callus induction from internodal explants of Tecomella undulata (Sm.) seem-A multipurpose medicinal plants. Intl. J. Scientific Res. 3(11).

Maity, S., S. Ray, and N. Banerjee. 2005. The role of plant growth regulators on direct and indirect plant regeneration from various organs of Leucaena leucocephala. Acta Physiol. Plant. 27:473-480.

Mathew, M.K., Y.S. Rao, K. Pradipkumar, K.J. Madhusoodanan, and S.N. Potty. 1999. In vitro culture system in vanilla. Osmania University, Hyderabad, India. p. 171-179. (Proc. Natl. Conf. Plant Tissue Cult. Biotechnol. Emerging Trends).

McCane, J. and D.A. Widdowson. 1992. In: Fruit and nut Suppl. To the composition of food, 5th ed. p. 74-77. Unwin \& Buss, London, Holland.

Mehta, U.J., S.M. Barreto, and S. Hazra. 2004. Effect of thidiazuron in germinating tamarind seedlings. In Vitro Cell. Dev. Biol. Plant 40(3):279-283.

Mok, C.M., W.S.D. Mok, J.E. Turner, and C.V. Mujer. 1987. Biological and biochemical effects of cytokinin-active phenylurea derivatives in tissue culture systems. J. Hort. Sci. 22:1194-1197.

Morton, J.F. 1987. Tree tomato, p. 437-440. In: J.F. Morton (ed.). Fruits of warm climates. Miami, FL.

Murashige, T. and F. Skoog. 1962. A revised medium for rapid growth and bioassays with tobacco tissue cultures. Physiol. Plant. 15:473497.

Ndoye, M., I. Diallo, and Y.K. Gassama. 2003. In vitro multiplication of the semi-arid forest tree, Balanites aegyptiaca (L.) Del. Afr. J. Biotechnol. 2(11):421-424.

Obando, M., A. Goreux, and M. Jordan. 1992. In vitro regeneration of Cyphomandra betacea (Tamarillo) and Andean fruit species. Cienc. Investig. Agrar. 19:125-130.

Obando, M. and M. Jordan. 2001. Regenerative responses of Cyphomandra betacea (Cav.) Sendt. (Tamarillo) cultivated in vitro. Acta Hort. 560:429-432.

Prohens, J. and F. Nuez. 2001. The Tamarillo (Cyphomandra betacea): A review of a promising small fruit crop. Small Fruits Review 1:43-68.

Rai, M.K., V.S. Jaiswal, and U. Jaiswal. 2009. Shoot multiplication and plant regeneration of guava (Psidium guajava L.) from nodal explants of in vitro raised plantlets. J. Fruit Ornam. Plant Res. 17(1):29-38.

Subramaniam, S., X. Rathinam, R. Poobathy, and U. Sinniah. 2008. In vitro production of multiple bud clumps (Mbcs) from Cavendish Banana cultivar, Brasilian (AAA). American-Eurasian J. Sustainable Agr. 2(3):300-307.

The Indian Agriculture Information Wing. 2009. Micropropagation of Tamarillo. Agricultural newsletter, p. 8. Agricultural Information Offset Press, Fruit Garden Meghalaya, Shillong, India.

Vasudevan, A., N. Selvaraj, P. Sureshkumar, and A. Ganapathi. 2001. Multiple shoot induction from shoot tip explant of cucumber (Cucumis sativus L.). Cucurbit Genet. Coop. Rep. 24: 8-12.

Waweru, B., R. Ishimwe, J. Kajuga, B. Kagiraneza, P.Y.K. Sallah, V. Ahishakiye, S. Kalisa, T. Asiimwe, J. Kahia, and D. Gahakwa. 2011. In vitro plant regeneration of Cyphomandra betacea (Tamarillo) through nodal culture. Rwanda J. 24: 58-66.

Zaffari, G.R., G.B. Kerbauy, J.E. Kraus, and E.C. Romano. 2000. Hormonal and histological studies related to in vitro banana bud formation. Plant Cell Tissue Organ Cult. 63(3):187-192. 